\title{
Effect of Phosphate Solubilizing Bacteria and Rhizobium on Growth and Yield of Legume Plants (Vigna radiata L. and Vigna mungo L.)
}

\author{
Krishna Kumari ${ }^{1}$, Shefali Poonia ${ }^{1}$, Purushottam ${ }^{2}$, Akash Tomar ${ }^{3}$, \\ R. Kumar ${ }^{2}$ B. P. Dhyani ${ }^{4}$ and Shanti Kumari ${ }^{* *}$ \\ ${ }^{1}$ Department of Botany, D.N. P.G. College, Meerut, India \\ ${ }^{2}$ Department of Pathology \& Microbiology, ${ }^{3}$ Department of Recombination Techniques, ${ }^{4}$ Soil \\ Science, S.V.P.U.A \& T., Meerut, India \\ ${ }^{5} \mathrm{SRF}, \mathrm{NAHEP}$, Project Implementation Unit, ICAR, New Delhi, Pusa Campus, India \\ *Corresponding author
}

\section{Keywords}

Green gram, Black gram, Rhizobium, PSB, Native Rhizobium and Native PSB

Article Info

Accepted: 04 October 2020 Available Online: 10 November 2020
A B S T R A C T

The experiments were conducted in the Department of Pathology \& Microbiology, Sardar Vallabhai Patel University of Agriculture and Technology, Meerut, during kharif season 2017-18, 2018-19 and 2019-20. The experiment was laid out in Completely randomized research design with three replicates and seven treatments. To the study the effect of PSB and Rhizobium on the seed germination, plant height, root length, shoot length, number of leaves, number of branches, number of pods, seed weight, grain yield and harvest index of green gram and black gram variety in different treatments. The P-value of seed germination percentage of Vigna radiata $L$. and Vigna mungo $L$ were found highly significant. The highest plant height $(17.50 \mathrm{~cm}$ and $27.69 \mathrm{~cm})$ was recorded, combined effect of IARI Rhizobium +IARI PSB and mean value combined treatments were observed with compared to control $(11.90$ to $18.67 \mathrm{~cm})$. The highest root length $3.30 \mathrm{~cm}$ and $4.40 \mathrm{~cm}$ were recorded and shoot length was 12.80 and 23.29. The green gram plants inoculated with IARI Rhizobium + IARI PSB, recorded the maximum root and shoot length $(4.40 \mathrm{~cm}$ and $23.29 \mathrm{~cm}$ ) followed by Native Rhizobium + Native PSB $(3.80 \mathrm{~cm})$ which were significantly superior over all strains. The plant inoculated with different IARI Rhizobium+ IARI PSB strains produced significantly higher mean $\left(13.60,12.39\right.$ plant $\left.^{-1}\right)$ number of leaves compared to control. The highest number of branches per plant 13.20 and 14.22 recorded which were treated with IARI PSB + IARI Rhizobium and the highest number of pods per plant 15.10 and 15.67 were recorded in treated with IARI PSB + IARI Rhizobium. Control treatment show a very less seed weight $\left(4.63,4.79 \operatorname{pot}^{-1}\right)$, while the plant treated with Native Rhizobium+ Native PSB $\left(6.94,7.63\right.$ pot $\left.^{-1}\right)$ show a significant increase in seed weight. The highest $\left(7.57,7.65\right.$ pot $\left.^{-1}\right)$ seed weight was recorded in the plants which were given IARI Rhizobium + IARI PSB treatments. The highest grain yield $\left(4.70 \mathrm{~g} \mathrm{ha}^{-1} / \mathrm{pot}^{-1}\right)$ was recorded in which treated with the Native Rhizobium+ Native PSB $\left(4.40,5.63 \mathrm{~g} \mathrm{ha}^{-1} / \mathrm{pot}^{-1}\right)$ increased compared to control $\left(3.10 \mathrm{~g} \mathrm{ha}^{-1} / \mathrm{pot}^{-1}\right)$ addressed with seed co-inoculation. The highest mean value $\left(3.24,3.56\right.$ pot $\left.^{-1}\right)$ of harvest index was recorded in plants which were treated with IARI Rhizobium + IARI PSB and Native Rhizobium+ PSB strains $\left(3.18,3.47\right.$ pot $\left.^{-1}\right)$ as compare to control pot. 


\section{Introduction}

Pulses occupy a prominent place in human nutrition, particular among the lower income group of people in developing countries like India. Important pulses growing in India are chick pea, pigeon pea, lentil, urd bean, mung bean, moth bean, pea, cow pea and broad bean etc. Mung bean Vigna radiata (L.) crop are important source of proteins, carbohydrates, dietary fibres, and minerals consumed worldwide. It is one of the most widely cultivated legume crops after Chickpea and Pigeon pea. Its nature is to India and Central Asia. Black gram Vigna mungo (L.) Hepper (= Phaseolus mungo, black gram, Uradbean) is an annual pulse crop native to central Asia. It is extensively used as staple crop in Central and South-east Asia and now grown in the Southern United States, the West Indies, Japan and other tropical and subtropical countries. It is a summer pulse crop with short duration and high nutritive value. It is valued for its high digestibility and freedom from flatulence effect. The average annual production of urad and moong are 3 and 2 MT respectively. India is the largest producer, consumer and importer of pulses in the world. It consumes an estimated 26 MT tonnes of pulses annually. The major pulse producing states in India are Andhra Pradesh, Orissa, Maharastra, Madhya Pradesh, Uttar Pradesh, Karnatka and Rajasthan. Pulses are mostly grown in two seasons Kharif and Rabi.

\section{Materials and Methods}

The present study entitled "Effect of Phosphate Solubilizing Bacteria and Rhizobium on Growth and Yield of Selected Legume Plants (Vigna radiata L. and Vigna mungo L.)." The experiment was carried out at the Department of Pathology \& Microbiology, Sardar Vallabhbhai Patel University of Agriculture and Technology,
Meerut, during Kharif 2017-2020. Seed of Vigna radiata and Vigna mungo were obtained from seed certification office, Meerut. Healthy seeds of uniform size were shorted out and washed with distilled water. The phosphate solubilizing bacteria and Rhizobium bacteria were procured from I. A. R. I., New Delhi. Collection and identification of native Rhizobium isolates was also done.

Method for isolation of PSB and Rhizobium culture medium used

Colony morphology and microscopy

Biochemical characterization

Seed germination assay

Pot experiment/testing- Parameters used for pot assay

\section{Pot Based Experiment/Testing}

Firstly, collected forty-twopots, then filled with eight $\mathrm{kg}$ sterilized soil and leave for 24 hours. Media was prepared YEM for Rhizoium and KB for PSB or seed treatment. Take one native PSB isolate +one native Rhizobium isolate, one IARI PSB isolate +one IARI Rhizobium isolate (PSB+RB). Four bacterial strains were inoculated in particular medium and incubate at $37^{\circ} \mathrm{C}$ or $48 \mathrm{hrs}$. Take seven sterilized petri plates and add approximate 20 seeds per Petri plate after that add $20 \mathrm{ml}$ bacterial solution. After that sowing the seed into pots. Observed the data during interval 15 days, 30 days and 45 days.

\section{Results and Discussion}

\section{Seed germination percentage of Vigna} radiata L. and Vigna mungo L.

The data presented in Table 1(a), 1(b) green gram and black gram, seed germination percentage were recorded from both treatments and it was observed that mean value significantly affected by the inoculation Rhizobium and PSB and its interaction 
between them at $\mathrm{P} \leq 0.01$. Similarly, the main effect of IARI Rhizobium+ IARI PSB was found significant at $\mathrm{P} \leq 0.05$. The anova analysis of seed germination percentage shows the effect of the treatment on the plants statistically. The P-value $(0.012)^{* *}(0.021)^{* *}$ $(0.01),{ }^{* *} \quad(0.026) * * \quad(0.042) * * \quad(0.029), * *$ shows highly significant results because the significance level $(0.27)^{* *}(0.11)^{* *}(0.32)$, $* *(0.07) * *(0.14) * *(0.46), * *$ more than $\mathrm{p}$ value. So it is also shows a significant effect of treatments on the given parameters. The data on mean seed germination percentage at 30, 45 and 60 days after sowing (DAS) were presented in Table 1(a), 1(b). The analysis of data revealed that among the (Pusa Vishal and Uttra) the highest seed germination percentage were found $47.33,56.67,85.33$, $55.00,81.00$, and 88.00, at 30, 45, and 60 DAS, respectively. The present study, coinoculants (IARI Rhizobium + IARI PSB) increased the percentage of seed germination, which is comparable with the result of (Gholami et al., 2009) who reported the increment of Vigna radiata seeds germination by $(38.67 \%$ and $35.67 \%)$ over control due to plant growth promoting rhizobacteria inoculants. The increase of seed germination with inoculants could be due to the isolates ability to synthesis seed germination hormone. (Gholami et al., 2009) demonstrated the enhancement of seed germination by inoculants because of the synthesis of seed germination hormone like gibberellins which triggered the activity of specific enzymes that promoted early germination, such as $\alpha$-amylase that increase the availability of starch assimilation.

\section{Plant height, root length and shoot length of green gram and black gram variety in different treatment}

The plant height which was obtained from mean values combined was significantly affected by the main effect of IARI Rhizobium
+ IARI PSB application and its interaction with inoculation at $\mathrm{P} \leq 0.01$. Similarly, the main effect of IARI Rhizobium+ IARI PSB was found significant at $\mathrm{P} \leq 0.05$ (Table 2(a) 2(b)). Moreover, this trait and its mean values was significantly influenced by the interaction of IARI Rhizobium+ IARI PSB and mean value combined treatment.

The anova analysis of plant height shows the effect of the treatment on the plants statistically non-significant green gram and significant result of black gram. The P-value $(0.255) * *(0.048),{ }^{* *}$ shows a highly significant results because the significance level $(0.087),{ }^{* *}(0.185)$, **less and more than p-value. So it is also shows a non- significant statistically.

The highest plant height $(17.50 \mathrm{~cm}$ and $27.69 \mathrm{~cm})$ was recorded, combined effect of IARI Rhizobium + IARI PSB and mean value combined treatments were observed with compared to control $(11.90$ to $18.67 \mathrm{~cm})$. The highest root length $3.30 \mathrm{~cm}$ and $4.40 \mathrm{~cm}$ were recorded and shoot length were 12.80 and 23.29 .

The application of fertilizers and inoculants significantly improved the growth attributes of mung bean. The increase in leaf area, leaf area duration and dry matter production by fertilization and inoculants might be due to efficient portioning and inoculants. The results also revealed that fertilizers and inoculants remarkably increased the plant height.

This increase in plant height can be due to vigorous vegetative growth as by the provision of nitrogen from fertilizer and inoculants.

These findings are in consistence with previous results of (Hussain et al., 2011) as they, reported substantial increase in plant height with nitrogen application. 
Number of leaves, number of branches and number of pods of green gram and black gram variety in different treatments

The data pertaining to number of leaves, number of branches and number of pods of green gram and black gram variety in different treatments presented in Table 3(a), 3(b) it revealed that the different treatments were found significant. The plant inoculated with different IARI Rhizobium+ IARI PSB strains produced significantly higher mean $\left(13.60,12.39\right.$ plant $\left.^{-1}\right)$ number of leaves compared to control. The height number of leaves was obtained in the plant which was treated with IARI Rhizobium + IARI PSB. The second highest mean $\left(12.20,10.88\right.$ plant $\left.^{-1}\right)$ number of leaves was obtained in the plant treated with the Native Rhizobium + Native $P S B$ strain, the lowest mean $(9.50,8.46$ plant ${ }^{-1}$ ) number of leaves was obtained in control. The findings are also similar to (Prasad Mithare et al., 2017).

The main effect of IARI Rhizobium+ IARI $P S B$ was found significant at $\mathrm{P} \leq 0.05$. The anova analysis of number of leaves shows the effect of the treatment on the plants statistically. The P-value $(0.025)^{* *}(0.071)$, ** shows a highly significant or non-significant results because the significance level $(0.084),{ }^{* *}(0.032)^{* *}$ more or less than $\mathrm{p}$ value, so this is also shows a significant effect of different treatments on treated plants.

\section{Number of branches plant ${ }^{-1}$}

In Table 3(a), 3(b) green gram and black gram, number of branches was responded significantly to the main effect of treatment with inoculation IARI Rhizobium + IARI PSB respectively at $\mathrm{P} \leq 0.05$. The analysis of variance also showed that the main effect of application (IARI Rhizobium+ IARI PSB) and its interaction with inoculation was significantly influenced this trait at both treatment and mean value combined over treated plants. Even this observation suggests number of branches increased with inoculation of IARI Rhizobium+ IARI PSB. The highest (13.20, 14.22 plant $\left.^{-1}\right)$ and lowest $\left(11.70,12.68\right.$ plant $\left.^{-1}\right)$ branches were obtained from application of Native Rhizobium+ Native PSB comparative to IARI fertilizer respectively. The highest number of branches were obtained in response to combined application of IARI Rhizobium + IARI PSB inoculation as well as application with the (9.50, 9.62 plant $\left.^{-1}\right)$ control treatment respectively. The highest mean value of branches over the treated plants $(13.20,14.22$ plant $^{-1}$ ) was obtained from combined application of IARI Rhizobium + IARI PSB inoculation which resulted in 3.7and $4.6 \%$ increase over the control check. Similar finding was reported by (Jitender et al., 2016).

The data presented in Table 3(a), 3(b) indicated that microbial inoculation and nutrients have significant effect on number of branches. The inoculation of IARI Rhizobium+ IARI PSB dual inoculation (IARI Rhizobium+ IARI PSB) were counted as $13.20,14.22$ plant $^{-}$ ${ }^{1}$ as comparison to un-inoculant counted 9.50 , 9.62 plant $^{-1}$. The combined seed inoculation with IARI Rhizobium + IARI PSB improved N and $\mathrm{P}$ status of soil and ultimately increased $\mathrm{N}$ and $\mathrm{P}$ uptake which enhanced growth attributes The nutrients application of NPK enhanced the branches per plant as comparison to control. Finding is in conformity with Gangwar and Dubey (2012). The interaction effects were found non-significant. The anova analysis of number of branches shows the effect of the treatment on the plants. The P-value (0.030), $* *(0.255) * *$ shows a highly significant and non-significant results because the significance level $\left.(0.087)^{* *}(0.084)\right)^{* *}$ more or less than $\mathrm{p}$ value, Hence this is also shows a highly significant and non-significant result statistically. 
Table.1(a) Seed germination percentage of green gram variety with different treatments

\begin{tabular}{|c|c|c|c|}
\hline Treatment & 30 DAS & 45 DAS & 60 DAS \\
\hline Control & 38.67 & 45.33 & 79.33 \\
\hline IARI Rhizobium & 40.33 & 49.67 & 82.67 \\
\hline Native Rhizobium & 37.67 & 46.33 & 82.33 \\
\hline IARI PSB & 40.33 & 51.67 & 83.33 \\
\hline Native PSB & 37.67 & 48.33 & 81.67 \\
\hline IARI PSB + IARI Rhizobium & 47.33 & 56.67 & 85.33 \\
\hline Native Rhizobium + Native PSB & 45.67 & 54.33 & 83.67 \\
\hline CD & $\mathbf{6 . 2 1 0}$ & $\mathbf{7 . 1 4 6}$ & $\mathbf{2 . 9 3 9}$ \\
\hline SE(m) & $\mathbf{2 . 0 2 8}$ & $\mathbf{2 . 3 3 3}$ & $\mathbf{0 . 9 5 9}$ \\
\hline
\end{tabular}

Significant $(* 0.01<\mathrm{P} \leq 0.05)$, Non-significant $(* 0.01>\mathrm{p}>0.05)$

Table.1(b) Seed germination percentage of black gram variety with different treatments

\begin{tabular}{|c|c|c|c|}
\hline Treatment & 30 DAS & 45 DAS & 60 DAS \\
\hline Control & 35.67 & 51.67 & 81.33 \\
\hline IARI Rhizobium & 45.33 & 64.33 & 86.33 \\
\hline Native Rhizobium & 41.67 & 60.33 & 85.67 \\
\hline IARI PSB & 49.33 & 66.67 & 86.67 \\
\hline Native PSB & 53.33 & 65.67 & 84.00 \\
\hline IARI PSB + IARI Rhizobium & 55.00 & 81.33 & 88.00 \\
\hline Native Rhizobium + Native PSB & 53.67 & 70.00 & 87.67 \\
\hline CD & $\mathbf{6 . 4 4 5}$ & $\mathbf{8 . 4 0 1}$ & $\mathbf{4 . 0 4 7}$ \\
\hline SE(m) & $\mathbf{2 . 1 0 4}$ & $\mathbf{2 . 7 4 3}$ & $\mathbf{1 . 3 2 1}$ \\
\hline
\end{tabular}

Significant $(* 0.01<\mathrm{P} \leq 0.05)$, Non-significant $(* 0.01>\mathrm{p}>0.05)$

Table.2(a) Root length and shoot length and plant height of green gram variety in different treatments

\begin{tabular}{|c|c|c|c|}
\hline Treatments & $\begin{array}{c}\text { Root length } \\
(\mathbf{c m})\end{array}$ & $\begin{array}{c}\text { shoot length } \\
(\mathbf{c m})\end{array}$ & $\begin{array}{c}\text { Plant height } \\
(\mathbf{c m})\end{array}$ \\
\hline Control & 2.30 & 9.60 & 11.90 \\
\hline IARI Rhizobium & 2.10 & 10.67 & 13.70 \\
\hline Native Rhizobium & 1.20 & 11.53 & 12.30 \\
\hline IARI PSB & 2.90 & 11.27 & 15.70 \\
\hline Native PSB & 1.90 & 12.80 & 14.10 \\
\hline IARI PSB + IARI Rhizobium & 3.30 & 12.27 & 17.50 \\
\hline Native Rhizobium +Native PSB & 1.90 & 12.36 & 16.20 \\
\hline CD & $\mathbf{0 . 6 0 1}$ & $\mathbf{1 . 6 0 8}$ & $\mathbf{1 . 6 4 9}$ \\
\hline SE(m) & $\mathbf{0 . 1 9 6}$ & $\mathbf{0 . 5 2}$ & $\mathbf{0 . 5 3 9}$ \\
\hline
\end{tabular}

Significant $(* 0.01<\mathrm{P} \leq 0.05)$, Non-significant $(* 0.01>\mathrm{p}>0.05)$ 
Table.2(b) Root length, shoot length and plant height of black gram variety in different treatments

\begin{tabular}{|c|c|c|c|}
\hline Treatments & $\begin{array}{c}\text { Root length } \\
(\mathbf{c m})\end{array}$ & $\begin{array}{c}\text { Shoot length } \\
(\mathbf{c m})\end{array}$ & $\begin{array}{c}\text { Plant height } \\
(\mathbf{c m})\end{array}$ \\
\hline Control & 1.50 & 16.47 & 18.67 \\
\hline IARI Rhizobium & 2.10 & 19.17 & 20.67 \\
\hline Native Rhizobium & 2.20 & 16.76 & 18.96 \\
\hline IARI PSB & 2.80 & 20.87 & 22.67 \\
\hline Native PSB & 2.70 & 22.68 & 26.38 \\
\hline IARI PSB + IARI Rhizobium & 4.40 & 23.29 & 27.69 \\
\hline Native Rhizobium +Native PSB & 3.80 & 21.21 & 25.01 \\
\hline CD & $\mathbf{1 . 2 3 4}$ & $\mathbf{3 . 7 8 0}$ & $\mathbf{1 . 8 4 6}$ \\
\hline SE(m) & $\mathbf{0 . 4 0 3}$ & $\mathbf{1 . 2 3 4}$ & $\mathbf{0 . 6 0 3}$ \\
\hline
\end{tabular}

Significant $(* 0.01<\mathrm{P} \leq 0.05)$, Non-Significant $(* 0.01>\mathrm{p}>0.05)$

Table.3(a) Number of leaves, number of branches and number of pods of green gram variety in different treatments

\begin{tabular}{|c|c|c|c|}
\hline Treatment & $\begin{array}{c}\text { Number of } \\
\text { leaves/plant }\end{array}$ & $\begin{array}{c}\text { Number of } \\
\text { branches/plant }\end{array}$ & $\begin{array}{c}\text { Number of } \\
\text { pods/plant }\end{array}$ \\
\hline Control & 9.50 & 9.50 & 10.60 \\
\hline IARI Rhizobium & 10.10 & 9.70 & 11.90 \\
\hline Native Rhizobium & 9.10 & 9.70 & 11.60 \\
\hline IARI PSB & 11.70 & 10.70 & 13.30 \\
\hline Native PSB & 10.50 & 9.90 & 11.40 \\
\hline IARI PSB + IARI Rhizobium & 13.60 & 13.20 & 15.10 \\
\hline Native Rhizobium + Native PSB & 12.20 & 11.70 & 13.40 \\
\hline CD & $\mathbf{1 . 9 9 9}$ & $\mathbf{2 . 1 7 9}$ & $\mathbf{1 . 9 8 9}$ \\
\hline SE(m) & $\mathbf{0 . 6 5 3}$ & $\mathbf{0 . 7 1 1}$ & $\mathbf{0 . 6 5 0}$ \\
\hline
\end{tabular}

Significant $(* 0.01<\mathrm{P} \leq 0.05)$, Non-Significant $(* 0.01>\mathrm{p}>0.05)$

Table.3(b) Number of leaves, number of branches and number of pods of black gram variety in different treatments

\begin{tabular}{|c|c|c|c|}
\hline Treatment & $\begin{array}{c}\text { Number of } \\
\text { leaves/plant }\end{array}$ & $\begin{array}{c}\text { Number of } \\
\text { branches/plant }\end{array}$ & $\begin{array}{c}\text { Number of } \\
\text { pods/plant }\end{array}$ \\
\hline Control & 8.46 & 9.62 & 9.67 \\
\hline IARI Rhizobium & 10.72 & 10.37 & 11.33 \\
\hline Native Rhizobium & 9.37 & 9.87 & 10.67 \\
\hline IARI PSB & 10.07 & 11.37 & 13.33 \\
\hline Native PSB & 9.43 & 10.30 & 12.33 \\
\hline IARI PSB + IARI Rhizobium & 12.39 & 14.22 & 15.67 \\
\hline Native Rhizobium + Native PSB & 10.88 & 12.68 & 14.67 \\
\hline CD & $\mathbf{2 . 1 7 4}$ & $\mathbf{2 . 6 2 0}$ & $\mathbf{2 . 8 6 2}$ \\
\hline SE(m) & $\mathbf{0 . 7 1 0}$ & $\mathbf{0 . 8 4 1}$ & $\mathbf{0 . 9 3 4}$ \\
\hline
\end{tabular}

Significant $(* 0.01<\mathrm{P} \leq 0.05)$, Non-significant $(* 0.01>\mathrm{p}>0.05)$ 
Table.4(a) Seed weight, grain yield and harvest index of green gram variety in different treatments

\begin{tabular}{|c|c|c|c|}
\hline Treatment & $\begin{array}{c}\text { Seed weight } \\
\text { g/pot }^{-1}\end{array}$ & $\begin{array}{c}\text { Grain } \\
\text { yield/g/ha }^{-1}\end{array}$ & $\begin{array}{c}\text { Harvest index } \\
\text { (HI) }\end{array}$ \\
\hline Control & 4.63 & 3.10 & 2.42 \\
\hline IARI Rhizobium & 5.90 & 3.40 & 2.44 \\
\hline Native Rhizobium & 4.68 & 3.30 & 2.43 \\
\hline IARI PSB & 6.69 & 4.20 & 2.56 \\
\hline Native PSB & 5.41 & 3.80 & 2.50 \\
\hline IARI PSB + IARI Rhizobium & 7.57 & 4.70 & 3.24 \\
\hline Native Rhizobium + Native PSB & 6.94 & 4.40 & 3.18 \\
\hline CD & $\mathbf{1 . 2 2 6}$ & $\mathbf{0 . 8 3 7}$ & $\mathbf{0 . 3 5 5}$ \\
\hline SE(m) & $\mathbf{0 . 4 0 0}$ & $\mathbf{0 . 2 7 3}$ & $\mathbf{0 . 1 1 6}$ \\
\hline
\end{tabular}

Significant $(* 0.01<\mathrm{P} \leq 0.05)$, Non-significant $(* 0.01>\mathrm{p}>0.05)$

Table.4(b) Seed weight, grain yield and harvest index of black gram variety in different treatments

\begin{tabular}{|c|c|c|c|}
\hline Treatment & $\begin{array}{c}\text { Seed weight } \\
\text { g/pot }^{-1}\end{array}$ & $\begin{array}{c}\text { Grain yield } \\
\text { g/ha }^{-1}\end{array}$ & $\begin{array}{c}\text { Harvest index } \\
\text { (HI) }\end{array}$ \\
\hline Control & 4.79 & 4.50 & 2.42 \\
\hline IARI Rhizobium & 6.54 & 5.50 & 2.81 \\
\hline Native Rhizobium & 5.98 & 5.10 & 2.40 \\
\hline IARI PSB & 6.66 & 4.90 & 2.72 \\
\hline Native PSB & 5.46 & 4.70 & 2.51 \\
\hline IARI PSB + IARI Rhizobium & 7.65 & 6.30 & 3.56 \\
\hline Native Rhizobium + Native PSB & 7.03 & 5.63 & 3.47 \\
\hline CD & $\mathbf{1 . 2 7 2}$ & $\mathbf{0 . 7 3 3}$ & $\mathbf{0 . 5 3 1}$ \\
\hline SE(m) & $\mathbf{0 . 4 1 5}$ & $\mathbf{0 . 2 3 9}$ & $\mathbf{0 . 1 7 3}$ \\
\hline
\end{tabular}

Significant $(* 0.01<\mathrm{P} \leq 0.05)$, Non-significant $(* 0.01>\mathrm{p}>0.05)$

\section{Number of pods plant ${ }^{-1}$}

In Table 3(a), 3(b) number of pods per plant was significantly affected by the main effect of IARI Rhizobium + IARI PSB inoculation of green gram and black gram were found significant $(\mathrm{P} \leq 0.05)$ respectively mean value combined over treatment. The analysis of variance also revealed that the highest mean value $\left(15.40,15.67\right.$ plant $\left.^{-1}\right)$ for number of pods was recorded in plants which were treated with Native Rhizobium + Native IARI PSB strains (13.40,14.67 plant $\left.^{-1}\right)$. Significant number of pods were recorded for the plants treated with IARI Rhizobium+ IARI PSB strains comparative to control (10.60, 9.67 plant $^{-1}$ ). The results obtained in this study show some interesting aspects on the growth effect of IARI Rhizobium+ IARI PSB inoculation in Vigna radiata and Vigna mungo which was grown in pots under environment. The results indicate the successful nature of usage of inoculation of Rhizobia + PSB to improve the growth effect of green gram and black gram. Similar findings were reported by (Lavanya and 
Toms, 2009; Mir et al., 2013). The P-value $(0.202) * *(0.032) * *$ shows a non-significant and significant results because the significance level $(0.446) * *(0.032), * *$ more or less than p-value, Hence it is also show a non-significant and significant result statistically.

\section{Seed weight $g$ pot $^{-1}$}

Number of seed weight exhibited a significant response to the main effect application of IARI Rhizobium + IARI PSB at $(\mathrm{P} \leq 0.05)$. The analysis of data given in Table 4(a), 4(b) shows the seed weight of green gram and black gram under the effect of all seven treatments. The plants which were not given any treatment i.e. control show a very less seed weight $\left(4.63,4.79\right.$ pot $\left.^{-1}\right)$. The plant treated with Native Rhizobium + Native PSB $\left(6.94,7.63\right.$ pot $\left.^{-1}\right)$ show a significant increase in seed weight. The highest $\left(7.57,7.65\right.$ pot $\left.^{-1}\right)$ seed weight was recorded in the plants which were given IARI Rhizobium+ IARI PSB treatments (Takankhar et al., 1997; Khoja et al., 2002) reported that Rhizobium+ PSB inoculation significantly increased seed weight of chickpea. The anova analysis for the seed weight shows a significant effect of treatments. The p-value $(0.053) * *(0.024) * *$ show the significant result because the significance level $(0.179)^{* *}(0.389),{ }^{* *}$ more or less than p-value, hence it is also show a highly significant result statistically.

\section{Grain yield $\mathrm{g} \mathrm{ha}^{-1}$ per pot}

In Table 4(a), 4(b) green gram and black gram, grain yield was significantly to the main effect of treatment with inoculation IARI Rhizobium + IARI PSB respectively at $\mathrm{P} \leq$ 0.05 . The analysis of variance also showed that the main effect of application (IARI Rhizobium+ IARI PSB) and its interaction with inoculation was significantly influenced this trait at both treatment and mean value combined over treated plants. From the data it was revealed that a significant increase in grain yield of mung bean was found with seed co-inoculation than un-inoculated treatments. The highest grain yield $\left(4.70 \mathrm{~g} \mathrm{ha}^{-1} / \mathrm{pot}^{-1}\right)$ was recorded in which treated with the Native Rhizobium+ Native PSB (4.40, 5.63 $\mathrm{g} \mathrm{ha}^{-1} /$ pot $\left.^{-1}\right)$ increased compared to control $(3.10 \mathrm{~g}$ $\left.\mathrm{ha}^{-1} / \mathrm{pot}^{-1}\right)$ addressed with seed co-inoculation. This finding reported by (Yousuf et al., (1989) Grain yield was significantly affected by different treatments (Table 4(a), 4(b)). The maximum grain yield $\left(6.30 \mathrm{~g} \mathrm{ha}^{-1} /\right.$ pot $\left.^{-1}\right)$ was recorded in treatment T7 (IARI Rhizobium+ IARI PSB) respectively, which were superior to rest of the treatments, while minimum was recorded in T1 (control). Grain yield was increased by $1.6 \%$ and $1.8 \%$ in treatment $\mathrm{T} 7$ over control $\left(4.50 \mathrm{~g} \mathrm{ha}^{-1} / \mathrm{pot}^{-1}\right)$. The result is supported by (Jain et al., 1999; Meena et al., 2002; Tanwar et al., 2002; Bhat et al., 2005; Band et al.,2007; Rathore et al., 2007). IARI Rhizobium + IARI PSB inoculation on urdbean was significantly increased in grain yield $\left(6.30 \mathrm{~g} \mathrm{ha}^{-1} / \mathrm{pot}^{-1}\right)$ as compared to without inoculation but its efficacy was significantly enhanced when inoculation was supplemented with phosphorus due to the synergistic effect of IARI Rhizobium +IARI $P S B$ inoculation over control. Highly significant increase was observed in combined application of Co-inoculation of IARI Rhizobium+ IARI PSB. The anova analysis for the seed weight shows a significant effect of treatments. The p-value $(0.014) * *(0.017) * *$ show the significant result because the significance level $(0.037)^{* *}$ $(0.046),{ }^{* *}$ more or less than p-value, Hence it is also show a highly significant result statistically.

\section{Harvest Index (HI)}

Harvest index determines the amount of photosynthesis being trans located to the economic parts of plant. Harvest index was 
influenced significantly $(\mathrm{P} \leq 0.05)$ due to the main effect of inoculation of IARI Rhizobium+ IARI PSB treated plants. The data showed that application of bio-fertilizers (IARI Rhizobium +IARI PSB) significant increase in harvest index in Table 4(a), 4(b) green gram and black gram, which resulted in better yield attributes ultimately there were beneficial effect on harvest index as compared to control, which was found to be $\mathrm{NP}$ of IARI Rhizobium + IARIPSB. The analysis of variance also revealed that the highest mean value $\left(3.24,3.56\right.$ pot $\left.^{-1}\right)$ of harvest index was recorded in plants which were treated with Native Rhizobium + Native IARI PSB strains $\left(3.18,3.47\right.$ pot $\left.^{-1}\right)$. Significant number of pods were recorded for the plants treated with IARI Rhizobium+ IARI PSB strains comparative to control $(2.42,2.42$ $\operatorname{pot}^{-1}$ ) of mungbean was obtained with the application of recommended dose of IARI Rhizobium +IARI PSB (20 ml liquid solution in pots), followed by treatments IARI Rhizobium + IARI PSB $\left(3.24,3.56\right.$ pot $\left.^{-1}\right)$. The combined inoculation of IARI Rhizobium+ IARI PSB with proved one of the most efficient approaches to in increasing in harvest index, nutrient content and uptake (Sharma et al., 2006). Dual inoculation might have contributed something towards enhanced harvest index and increased nitrogen or soluble phosphorus. Increased growth parameters with dual inoculation with IARI Rhizobium +IARI PSB were observed in mung bean. Similar finding reported by (Varghese2011; Meena et al., 2013). The anova analysis for the seed weight shows a significant effect of treatments. The p-value $(0.011) * *(0.019) * *$ show the significant result because the significance level $(0.029)^{* *}$ $(0.042),{ }^{* *}$ more or less than p-value, Hence it is also show a highly significant result statistically

In conclusion the P-value of seed germination percentage in Vigna radiata L. and Vigna mungo $L$. were found highly significant with treatment of IARI Rhizobium + IARI PSB. The highest plant height, root length and shoot length were recorded in inoculated with Rhizobium $+P S B$ treated plants. The number of leaves, number of branches and number of pods were recorded in treated plants with IARI PSB + IARI Rhizobium. The higher per plant/per pot seed weight and grain yield was recorded in the plants which were given IARI Rhizobium + IARI PSB treatments and Native Rhizobium+ Native PSB. The significant increase in grain yield of mung bean and black gram was recorded with seed coinoculation as compare to un-inoculated treated seed. Application of bio-fertilizers (IARI Rhizobium + IARI PSB) significant increase in harvest index.

\section{References}

Band, A.M.,Mendhe, S.N., Kolte, H.S., Choudhary, R.L., Verma, R. and Sharma, S.K. (2007) utrient management studies in French bean (Phaseolus vulgaris L.). Journal of Soils and Crops, 17(2): 367-372

Bhat, S.A., Thenua, O.V.S. Shivakumar, B.G. Malik, J.K. (2005) Performance of summer greengram [Vigna radiata (L.)] as influenced by biofertilizers and phosphorus nutrition. Haryana Journal of Agronomy, 21(2): 203-205.

Gholami, A., S. Shahsavani and S. Nezarat, (2009). The effect of Plant Growth Promoting Rhizobacteria (PGPR) on germination, seedling growth and yield of maize. World Academic Science Engineering Technology, 49: 19-24.

Hussain N., Medhi M. and Kant R.H.(2011). Response of Nitrogen and Phosphorus on growth and yield attributes of black gram (Vigna mungo L.). Agricultural Science Research Journal, 2: 41- 45.

Jain, P.C., Kushwaha, P.S., Dhakad, U.S., 
Khan, H., Trivedi, S.K. (1999) Response of chickpea (Cicer arietinum L.) to phosphorus and Biofertilizer. Legume Research, 22(4): 241-244

Jitender, et al., (2016) Effect of Integrated Crop Management on Seed Yield in Mungbean (Vigna radiata L. Wilczek). International Journal of Agricultural Sciences, Vol.8(60): 3364-3366.

KhojaJ.R, Khangarot S.S, Gupta A. K. andKulhari A. K. (2002) "Effect of fertilizer and biofertilizers on growth and yield of chickpea," Annals of Plant and Soil Research, vol. 4:357358.

Lavanya, G.R. and Toms, B. (2009) Association and interrelationship among yield contributing characters inmungbean. Journal of Food Legumes, 22: 65-67.

MeenaRS, Ramawatar, Kamalesh A, Ram K.(2013). Effect of organic and inorganic source of nutrients on yield, nutrient uptake and nutrient status of soil after harvest of greengram. An Asian Journal of Soil Science, 8(1): 80-83.

Mir, A. H.; Lal, S. B.; Salmani, M.; Abid, M. and Khan, I. (2013). growth, yield and nutrient content of Blackgram as influenced by levels of phosphorus, sulphur and phosphorus solubilizing bacteria. SAARC Journal Agriculture,
11(1): 1-6.

PrasadMithare, Joy Dawson (2018) Review on: Response of secondary, micro nutrients and naphthalene acetic acid (NAA) on growth, yield and quality of blackgram (Vigna mungo (L.)) Journal of Entomology and Zoology Studies,6(4): 779-785

Rathore, V.S., Singh, J.P., Soni, M.L., Beniwal, R.K. (2007) Effect of nutrient management on growth, productivity and nutrient uptake of rainfed clusterbean (Cyamopsis tetragonoloba) in arid region. Indian Journal of Agricultural Sciences, 77 (6): 349-353.

Sharma, P., Gupta, R. P. and Khanna, V. (2006). Evaluation of liquid Rhizobium inoculants in mungbean, urdbean and pigeonpea under field conditions. Indian Journal of Pules Research,19: 208-209.

Takankhar V. G., Mane S.S.,Kamble B. G. and Indulkar B. S., (1997) "Grain quality of chickpea as influenced by phosphorus fertilization and Rhizobium inoculation," Journal of the Indian Society of Soil Science, vol. 45(2): 394-396,

Varghese N. (2011) Changing directions of groundnut trade in India: The WTO effect. International conference of applied ecology, 731.

\section{How to cite this article:}

Krishna Kumari, Shefali Poonia, Purushottam, Akash Tomar, R. Kumar, B. P. Dhyani and Shanti Kumari. 2020. Effect of Phosphate Solubilizing Bacteria and Rhizobium on Growth and Yield of Legume Plants (Vigna radiata L. and Vigna mungo L.). Int.J.Curr.Microbiol.App.Sci. 9(11): 332-341. doi: https://doi.org/10.20546/ijcmas.2020.911.040 